\title{
IMPACT OF EU GRANTS ON EDUCATION IN KOSOVO
}

\author{
Prof.Ass.Dr.Theranda Beqiri ${ }^{1}$ \\ Ms.sci.Arbërora Haxhija² \\ ${ }^{1}$ University Haxhi Zeka, Faculty of Business \\ Theranda.Beqiri@unhz.eu \\ ${ }^{2}$ Agency for Western Regional Development \\ Arbërora.Haxhija@ardawest.eu
}

\begin{abstract}
The main purpose of this paper is to present the investments made so far and the impact of these investments on the development of human capacities. This paper will also identify the potentials and needs for further development of human resources in both formal education and vocational training. It is important that the population of Kosovo is well prepared for Kosovo's integration into the European Union so that future investments are oriented towards sustainable development through long-term investment policies and strategies. Although there are some reforms in Higher education still many reforms are needed to be implemented also in primary and secondary education. There is a need for skills that match the labor market needs and creation and development of these skills depends mainly on the quality of the education system, its relationship with the labor market, the conditions in which people work in the labor market, but also the opportunities to gain skills through vocational trainings or further educations.. Vocational training is very low, while at least a quarter of vocational schools do not offer internships in or out of school. Enterprises have no incentives to hire interns and in educational institutions there are limited career guidance although we found that grants have had their impact in higher education in improving the policies and curriculum development in each level of educations and through different trainings of teachers in primary and secondary schools. We find that although there is a high level of grants in education sector, a lot of resources are still needed to enhance the education quality in all levels, there is a need of infrastructure and increased improvement in curricula that than impacts in the increased quality of education.
\end{abstract}

Key words: Grants, Education, Curricula, Strategy, Training, EU,

\section{Introduction}

Kosovo is one of the countries that during the post-war period have witnessed many phenomena that society had to build up as a consequence of the conflict. Being among the youngest countries in the world, Kosovo faces many challenges and difficulties to become a member with equal rights in the large family of the European Union. The gradual weakening of the industry, the constant obstacles to sustainable development and, more importantly, the difficulty of maintaining the teaching process have influenced Kosovo as a society to lag behind the countries of the region. In this context, the international community in order to support the recovery of state has decided various bodies to operate in Kosovo aiming at supporting the sustainable economic development. Since 1999, the United Nations Interim Administration Mission (UNMIK) has been leading the state of Kosovo by governing municipalities and managing Kosovo's state assets. During this period, almost all socially-owned enterprises in Kosovo have been privatized, replacing almost the entire existing industry with private ownership. At the same time, many other donors have invested through donations in the recovery of our state. Different donors such as USAID, KFW, GIZ, Swiss Contact, SIDA through their programs have supported different programs and sectors. Undoubtedly, the European Union is one of the supporters of Kosovo through grants and technical assistance in Kosovo. The EU is present in Kosovo through the Special Representative in Kosovo. The EU Office in Kosovo has played a key role in international efforts to build a new future for Kosovo since 1999.Kosovo has received more than $€ 2.3$ billion since 1999 and nearly $€ 1$ billion to support Kosovo's international presence in the European Union alone. Given the full support provided by the EU as well as other implementing donors of investment programs of various governments, we need to think about the outcome of these investments and look closely at the impact of these funds on the development of human resources. The mismatch of labor market needs 
with the knowledge gained in higher and vocational education has been identified as one of the main obstacles to employment growth and economic development in the country. About $25 \%$ of firms in Kosovo still complain that the workforce has incomplete and incompatible skills. On the other hand, more than $85 \%$ of investors underline the quality of the workforce as the main factor when making investment decisions. The education sector is still affected by the lack of adequate facilities, maintenance and quality assurance. Crucial challenges to be tackled in the education sector include improving the quality of primary and secondary education, vocational education and training; strengthening transparency in the education system; investment in teacher skills. When we talk about skills, we are not only talking about technical skills, such as cutting and shaping a product, but also about cognitive skills, such as logic and reasoning, or soft skills such as relationships with colleagues or work ethic. The creation of these skills depends mainly on the quality of the education system, its relationship with the labor market, the conditions in which people work in the labor market, but also the opportunities to gain skills through vocational trainings or further educations.

\section{Insights from Kosovo Region}

The Republic of Kosovo is at an important stage when the development agenda should be oriented towards European integration in all areas. Such a European development orientation comes naturally after overcoming the emergency and stabilization phase during 1999-2007, and the state-building phase in the period after the declaration of independence. During the emergency and stabilization phase, we as a society together with our international partners focused on rebuilding the destroyed basic infrastructure as well as creating normal living conditions. Then, in the construction state phase, our energies were oriented towards the construction of the institutional architecture of the state as well as the elementary physical infrastructure for development and wellbeing. Thus, public investments were oriented towards the creation of new state institutions, the development of educational and health infrastructure, as well as other infrastructure necessary for sustainable development. While economic growth rates have been modest in recent years, including the global economic crisis - an average of $3.3 \%$ a year since 2009 - and have had an effect on reducing overall poverty levels, they are likely to be even higher. In fact, they need to be higher to enable Kosovo to develop sustainably and meet higher living standards. Per capita income in Kosovo is at the level of $11 \%$ compared to European Union countries and to achieve this level of the EU. The Table 1 below shows the comparison of five selected indicators Kosovo needs a growth rate of about $8 \%$ for the next 30 years. Also, given that Kosovo stands behind the average of Southeast European countries that are not members of the EU based on a number of key economic and social indicators, which speak to the level of economy and quality of life, initially the goal ours is to achieve the level of these places (illustrated in the table below).

Table 1. Comparison of five selected indicators

\begin{tabular}{|l|l|l}
\hline Indicator & Kosova & $\begin{array}{l}\text { Average of Southeast European countries } \\
\text { that are not members od EU }\end{array}$ \\
\hline Gross local product per capita & $€ 2.935$ & $€ 3.504$ \\
\hline Unemployment rate & $30,1 \%$ & $20,8 \%$ \\
\hline Participation in the labor market & $40,5 \%$ & $49,7 \%$ \\
\hline Percentage of the population living in poverty & $29,9 \%$ & $19,7 \%$ \\
\hline The ratio between exports and imports & $12 \%$ & $46.5 \%$ \\
\hline
\end{tabular}

Source; Indicative strategy paper for Kosovo

\section{Materials and Methods}

Based on economic theory human capital offers an alternative logic to understand the choices that firms make in human resource management. The essence of this theory is that people are valuable to the organization to the 
extent that they make it productive. Thus, organizations need to make decisions about investing in people just as they make decisions about investing in machinery; they need to treat their employees as a form of their capital. Expenditures related to training, retraining, motivation and monitoring of the organization are seen as investments in the human capital of the firm as well as the maintenance of machinery would constitute an investment in the firm's capital. Human capital theory can be used to gain knowledge in decisions where firms organize or reorganize for their staff and their human capital operations. A standard approach from the point of view of the labor economy, human capital is presented by the characteristics as well as the skills that increase the productivity of employees. This can generally be taken as a general definition, but there are many studies that have contributed and provided some alternative and complementary thoughts on human capital. According to (Becker, 1964), human capital is directly needed in the production process, more explicitly human capital increases the productivity of employees in all tasks, but normally differently in different tasks and different organizations, e. which although generalized makes sense since the level of knowledge and ability of employees is directly related to the function of productivity. When it comes to grants in education according to Carneiro et al (2020) sometimes government and authorities does not know the needs of the schools and universities and therefore we do not see improvement in their general scores .whilst when comes to the labor market to select and retain a satisfying employee there are some issues that needs to be developed as training and development and interaction of organizations strategy with human resources development, in order to reach competitive advantage in the field that they are working Holland et al (2007). Sun, M., Penner, E. K., \& Loeb, S. (2017). Whilst Sun \& Loeb (2017) in their research analyzing grants for low performance schools found that the improvements in the success of schools takes long time and improvements in the performance of the schools can be seen only in the third year of grants. Bing, Kehrhahn \& Short, (2003) say that human resources development should be integral part of the organizations taking into account short and long planning which is than correlated with the increased wellbeing of the society rather than just as an internal issue of the organization. Okoye \& Ezejiofor (2013) exploring the effect of human resources development on organizational productivity.

\section{Methods of research}

The main purpose of this paper is to present the investments made so far and the impact of these investments on the development of human capacity. Also, through this work, the potentials and at the same time the needs for further development of human resources will be identified, both by professional and technical trainings. It is important for Kosovo's integration into the European Union so that future investments can be oriented towards sustainable development through long-term investment policies and strategies. The methods that are used is mainly through secondary data through analyzing of investments and grants in Kosovo from the EU donors through different reports, also it is analyzed the impact of these investments on human resources and the impact on sustainable economic development taking into account the human factor, drawing conclusions and recommendations for planning and orienting investment funds regarding the development of human resources. We use the data from the time period of 2008 until 2015 and do some comparisons and analysis, as well as further donations and strategies in recent years.

The research questions are:

1. What strategies and plans have been used by the institutions and what are the processes and activities should be undertaken in order to successfully implement these strategies?

2. How will the impact of these undertaken activities be assessed and measured?

3. What are the benefits to society of achieving these specific objectives?

\section{Results}

\section{EU Investments in the Education Sector in Kosovo 2008-2015}

This part of the paper presents the plans and policies of the central institutions and line ministries regarding the activities and measures for the development of human resources as well as the main donor for Kosovo, the European Union. As we have seen in the indicative plans the development of human resources and employment is one of the five areas of action foreseen with the strategic document for Kosovo from IPA II funds, a total of 645 million euros. This part of the paper also reflects the investments made in this sector by the European Union. 
The data are taken from the annual reports of the Ministry of European Integration for sector and donor. As can be seen from the graphs below presented for this reporting period, the EU is the donor who leads the investments made for the period 2008 - 2015. Sector Education and employment is composed of six sub-sectors: employment, welfare and inclusiveness, higher education, research and innovation, pre-university education, vocational training and education (teaching for adults and throughout life), youth and other employment and education. Including cultural, recreational and heritage activities. Based on this report, from 2008 to 2015, donors spent approximately 215.6 million euros.

Fig.1 Presentation of planned and current distribution (2008-2015) in the education and employment sector

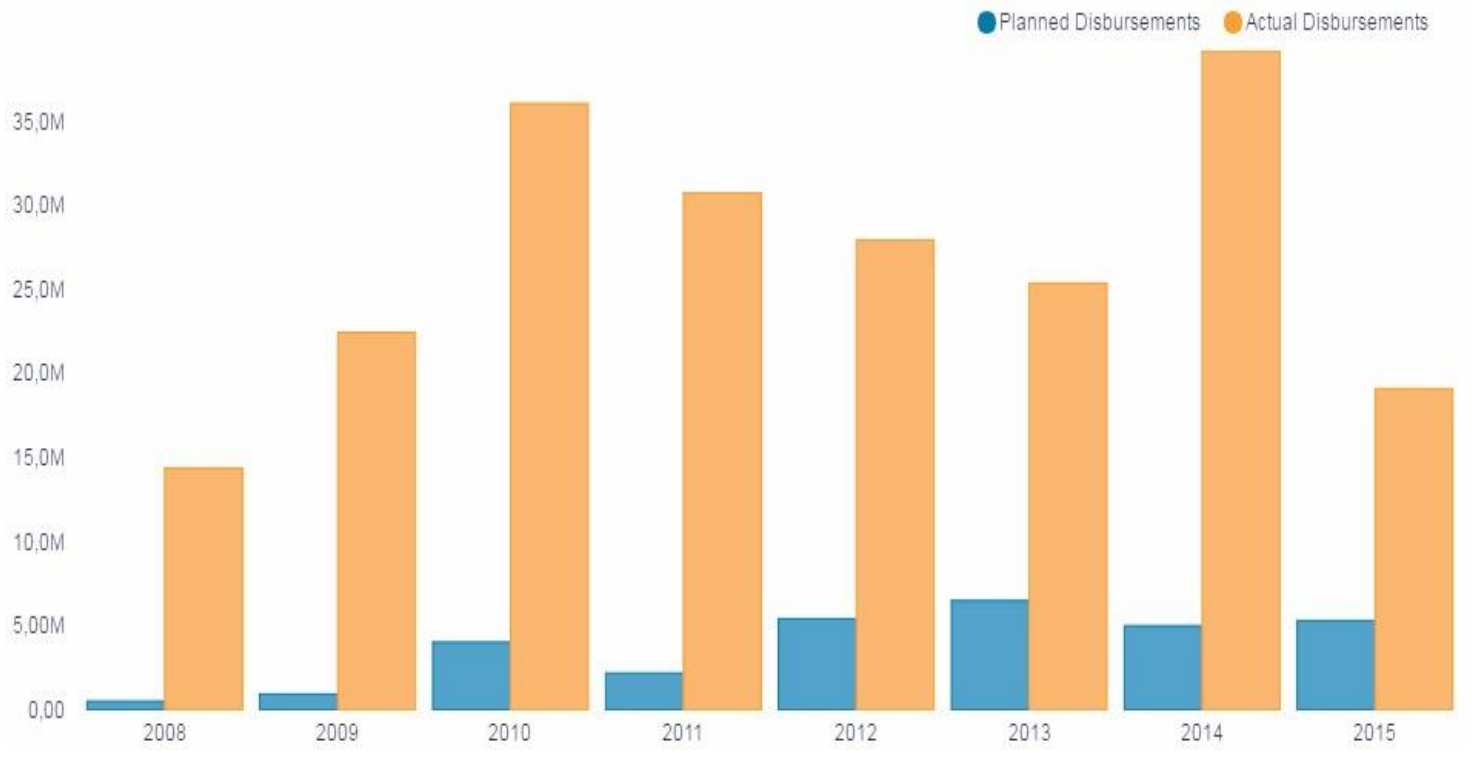

Source; Ministry of European Integration Annual Report Donor Profiles, MEI, 2016

According to the report for Kosovo Indicative Strategy, (IPA II) Kosovo does not have a comprehensive development strategy. However, a large number of medium-term strategies exist. According to the Indicative Strategy Paper for Kosovo, IPA II, steps have been taken in this direction in recent years, but a long-term strategy for Kosovo is lacking. In general terms, even sector planning is at an early stage. Although, comprehensive and realistic strategies have been developed in some sectors by the relevant ministries, often these strategies have been designed with the help /and assistance of various donors among which is also the Strategic Plan for Education in Kosovo 2011-2016. The Employment and Welfare Strategy 2014-2020 is a comprehensive strategy aimed at improving the functioning of the labor market, promoting the development of skills, covering the welfare system and consolidating the role of social partners. From the data below table 3 we can see the level of donors in education and employment sector while in many currencies (million euros) we can see the levels of donations of EU compared with other donators. 
ISSN 2661-2666 (Online) International Social Science Journal Monte DOI: 10.33807/monte.202004675 Volume 3 No. 1 (2020): April

Table 3 .Percentage of donors in the Employment and Education sector 2008-2015,

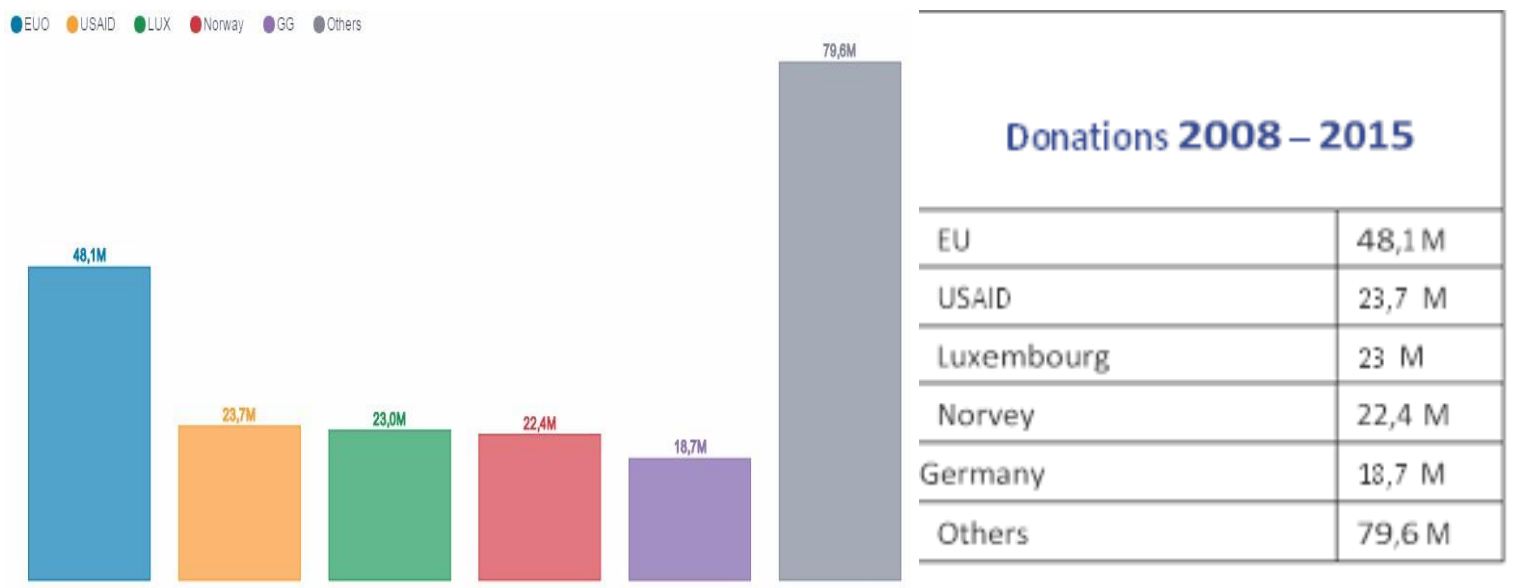

Source; Annual Report Donor Profiles, MEI, 2016

\section{Discussions}

If we consider some indicative targets from the strategy paper (2014-2020) some of the main challenges for Kosovo are; increase of enrolment of pupil's students in all levels of education, improving infrastructure, increasing the quality of education, increasing participation of students in vocational education and matching the skills with needs of the labor market. If consider the public spending around $4 \%$ of the GDP is spent in education sector. Furthermore, according to strategy paper pg44 (2014-2020) " $75 \%$ of overall spending on education is for salaries and increases in education spending are used almost entirely for salary increases rather than education quality improvement (only $0.2 \%$ of education spending was allocated for training of teachers)". Although the strategic plan 2016-2021 says that the focus shall be oriented in training of teaching staff and to ensure a professional development of teachers should be based on unified standards. Although there are teacher trainings especially staff in primary and secondary education, the trained teachers teach with old text books. If we consider the curriculum development in 2011, MEST produced a new Kosovo Curriculum Framework (CCF) with the aim of increasing the quality of education and harmonization of education with developed countries. Analysis of Kosovo's Education System, (2020) This new curriculum framework ensured the transition from teaching based objectives and content to performance-based teaching and student. Human resources are the active agents who accumulate wealth, exploit material resources, build socio-economic and political organization and carry out national development. Highly skilled human resources are a pre-requisite for overall economic and national development. For many researchers, human resources are the greatest asset of an organization or company, and the knowledge gained from work experience called "unwritten knowledge" is also an added value for any conscious employer. (Millmore, 2007). While continuous investment in the advancement of knowledge and skills of human resources creates a competitive advantage for the organization or company (Mathis \& Jackson, 2011). For Kosovo according to the study conducted from Beqiri \& Mazreku (2020) the most commonly used trainings for workers in Kosovo are on job and seminar trainings, and although traditional organizational training and development programs are still useful, the new forms of development, such as rotations and coaching, start to play their role in self-directed and self-designed careers. Zaleska \& Meneze (2007). Human resources development practices and their association with employee attitudes: Between traditional and new careers. Despite the relatively large number of vocational schools and teaching fields that they provide, MEST in the Strategic Plan of Education in Kosovo (PSAK) 2011-2016 identifies a range of challenges in this sector, such as inadequate budget, insufficient learning spaces in a single shift, improving the professional capacity of human resources for system management and in teaching, improving the quality and relevance of curricula with market demands, adequate development of the qualification framework in accordance with the European one, as well as, among other things, establishing better links with enterprises for practical work goals. Consequently, the same document from MEST identifies priority for this education sector to address existing challenges and sets clear goals which through programs and activities must be achieved long planned period. The main challenges in the education sector are the improvement of quality in primary and secondary education, vocational education and training; strengthening transparency in the education sector; investments in teaching skills Higher education in Kosovo is a matter of 
linear reform with the Bologna system, but many reforms still need to be implemented. Participating in the Erasmus + program and its external dimension by supporting the modernization of higher education is in first steps in increasing the quality of higher education. Carneiro et al (2020) found that impact of grants in education in quality and learning has its impact when its combined with government and heads of school's involvement 'especially on girls and students with high ability levels at baseline, at a cost effectiveness rate commensurate with other interventions that aim to improve education outcomes in low-income countries'. In Kosovo population is the youngest in Europe and unemployment levels are approximately as high as 35 percent. Of the many unemployed, $60 \%$ of them do not have basic skills for labor market. However, the number of unemployed people with university education has increased, thus signaling a discrepancy between the skills needed for the labor market and those provided by the education system. Increasing the level and relevance of the skills of the workforce is one of the main challenges

\section{Conclusions}

Kosovo today is not in a good position in comparison with the region in terms of workers skills. At a time when unemployment in the country is very high, the paradox is that many enterprises have trouble finding skilled workers. One of the main reasons lies in the education system, namely the low involvement of the pupils in the secondary schools and the quality of teaching. Another problem is the lack of compliance of skills and abilities acquired with the demands of the labor market, as there is a lack of connections and collaboration in the triangle between schools, businesses and communities. There is no system in Kosovo for forecasting the skills required in the labor market. The process of drafting professional qualification standards is slow, as is the implementation of the Curriculum Framework. The level of public spending on education and vocational training is very low, while at least a quarter of vocational schools do not offer internships in or out of school. Enterprises have no incentives to hire interns. Schools offer limited career guidance nor enterprise connectivity opportunities through product research and development. However, even in the case of these areas, Kosovo would benefit greatly from the establishment of one or more Competence Centers, where the knowledge and skills acquired in these institutions would be complemented by special training programs. Also, creating partnerships with the private sector to establish training centers that offer international certification programs in hotel and tourism, financial and business services, and foreign languages would improve the region's competitiveness to attract investment, and would create greater employment and self-employment opportunities for the region's population. o strengthens the link between educational programs and labor market needs through the definition of professional standards and priority areas, as well as the implementation of core curricula and teacher training. The vocational education system will become as practical as possible, including internships at the enterprises. 
ISSN 2661-2666 (Online) International Social Science Journal Monte DOI: 10.33807/monte.202004675 Volume 3 No. 1 (2020): April

\section{References}

Becker, G. (1964). human capital, NY. GS Becker.

Beqiri, T., \& Mazreku, I. (2020). Lifelong Learning, Training and Development Employee's Perspective. Journal of Educational and Social Research, 10(2), 94-94.

Bing, J. W., Kehrhahn, M., \& Short, D. C. (2003). Challenges to the field of human resources development. Advances in Developing Human Resources, 5(3), 342-351.

Carneiro, P., Koussihouèdé, O., Lahire, N., Meghir, C., \& Mommaerts, C. (2020). School Grants and Education Quality: Experimental Evidence from Senegal. Economica, 87(345), 28-51.

Holland, P., Sheehan, C., \& De Cieri, H. (2007). Attracting and retaining talent: Exploring human resources development trends in Australia. Human Resource Development International, 10(3), 247-262.

Mathis, R. L., \& Jackson, J. H. (2011). Human resource management: Essential perspectives. Cengage Learning.

Millmore, M., \& Lewis, P. (2007). Strategic human resource management: contemporary issues. Pearson Education.

Okoye, P. V. C., \& Ezejiofor, R. A. (2013). The effect of human resources development on organizational productivity. International Journal of Academic Research in Business and Social Sciences, 3(10), 250 .

Perlman, C. L., \& Redding, S. (2011). Handbook on Effective Implementation of School Improvement Grants. Academic Development Institute.

Sun, M., Penner, E. K., \& Loeb, S. (2017). Resource-and approach-driven multidimensional change: Three-year effects of School Improvement Grants. American Educational Research Journal, 54(4), 607-643.

Zaleska, K. J., \& de Menezes, L. M. (2007). Human resources development practices and their association with employee attitudes: Between traditional and new careers. Human relations, 60(7), 987-1018.

Analysis of Kosovo's Education System,(2020) Aliu Luljeta 2020 Friedrich Ebert Foundation retrieved from URL http://library.fes.de/pdf-files/bueros/kosovo/15185-20190220.pdf Accessed $21^{\text {st }}$ of march 2020

Indicative Strategy Paper for Kosovo (2014-2020) retrieved from URL https://eeas.europa.eu/headquarters/headQuarters-homepage/50070/indicative-strategy-paper-kosovo2014-2020_ku accesed 7th april 2020

Indicative Strategy Paper for Kosovo, retrieved from URL https://ec.europa.eu/neighbourhoodenlargement/sites/near/files/20180817-revised-indicative-strategy-paper-2014-2020-for-kosovo.pdf

MIE, 2015 sector screening report, retrieved from URL https://www.mei-

ks.net/repository/docs/anualreportsectorscreening.pdf aaccessed20th of January 2020

MIE, 2016 Annual report Donor profile MIE, retrieved from URL https://www.meiks.net/repository/docs/anualreport_english_3.pdf accesed 5th ofnovember 2019

Strategjia Kombetare per Zhvillim 2016-2021 ( SKZH) retrieved from URL http://www.kryeministriks.net/repository/docs/Strategjia_Kombetare_per_Zhvillim_2016-2021_Shqip.pdf accessed 5th of march 2020 